\title{
Primary squamous cell carcinoma of the breast: About one case and review of the literature of the last ten years
}

\author{
Karl Wehbe $^{1 *}$, Christian Garbar ${ }^{2}$, Vivien Ceccato ${ }^{1}$ and Clement Dabiri ${ }^{1}$ \\ ${ }^{1}$ Department of Surgery, Institut Jean Godinot - Unicancer, Reims, France \\ ${ }^{2}$ Department of Biopathology Department, Institut Jean Godinot - Unicancer, Reims, France
}

\begin{abstract}
Abbreviations: PSCCB: Primary squamous cell carcinoma of the breast; PET: Positron emission tomography; DCIS: Ductal carcinoma in situ
\end{abstract}

\section{Introduction}

Primary squamous cell carcinomas of the breast belong to the group of metaplastic carcinomas of the breast. The World Health Organization (WHO) defines these tumors as "a carcinoma of the breast composed entirely of metaplastic squamous cells that can be keratinizing, nonkeratinizing or tapered". They are not derived from the overlying skin nor do they represent metastases from other sites [1]. In common practice, most pathologists do not exclude cases with a small ductal or ambiguous differentiation component, as indicated in Rosen's Breast Pathology for whom pure squamous forms are defined by "the presence of a squamous component in more $90 \%$ of the tumor cells" [2]. The diagnosis, particularly the primitive nature, can only be asserted after having eliminated all other potential sites of squamous cell carcinoma.

PSCCB are infrequent, the prevalence is estimated at about $0.1 \%$ of breast carcinomas [3,4]. Due to the rarity of this pathology, most studies on the subject are sporadic cases or small series. Their characteristics therefore remain poorly understood, and their management is often extrapolated from that of more common forms of malignant breast tumors, such as invasive ductal or lobular carcinomas.

To date, the prognosis and optimal treatment of PSCCB remains controversial. Some authors have estimated that there are no significant differences between the prognosis of PSCCB and that of other mammary malignancies $[5,6]$. Other authors have suggested a darker prognosis [7-9].

We propose a description of a case of PSCCB supported in the service of cancer surgery of the Jean Godinot Institute accompanied by a review of the literature on the subject.

\section{Clinical case}

A 49-year-old woman was treated in our department for a primary squamous cell carcinoma of the breast discovered after surgery to flatten a left breast abscess.

She had undergone a left breast lumpectomy a year before for a non-suspect intraductal papilloma associated with a modified squamous cell cyst. She later presented several local inflammatory episodes complicated by an abscess of the initial operative site treated by flattening and surgical drainage.

Histopathological analysis of the excision specimen revealed squamous cell carcinoma of $22 \times 22 \times 30 \mathrm{~mm}$ in a cystic lesion lined by a well-differentiated, keratinizing and slightly papillomatous squamous epithelium. This lesion was clearly invasive and associated with a characteristic tumor stroma. It was just under the epidermis, in the deep dermis and the hypodermis, in contact with some mammary lobules or cutaneous appendages. There was no ductal carcinoma in situ of the associated breast or lesions of dysplasia within the epidermis. Immunohistochemistry was positive for $5 / 6$ cytokeratins and p63. The estrogen and progesterone receptors were negative as was the Her2 status. Due to the margins reached, a totalization of the excision associated with the sentinel lymph node technique was performed. The three cuttings were negative and 3 of the 5 ganglia removed were metastatic from squamous cell carcinoma. A complementary left axillary dissection revealed 21 healthy ganglia. A PET scanner was performed as part of its extension assessment and did not reveal any suspicious secondary localization. The lesion was classified pT2 pN1 M0. Adjuvant axillary and supraclavicular radiotherapy of 50 Gy was performed.

Two years after the end of radiotherapy, as part of its surveillance, a PET scanner showed an increase in the size of intra-mammary lesions compared to the left breast scar without any argument for secondary localization. Until now, microbiopsies found only postoperative changes with a significant inflammatory reaction of the chronic xanthogranulomatous type, presumably indicative of an old hematoma (Figure 1-3). Level II oncoplastic lumpectomy was performed (Figure 4). Histopathological analysis revealed an intra-mammary metastasis of well-differentiated squamous cell carcinoma of $0.5 \mathrm{~cm}$ and an abscess being organized (Figure 5). Also noted was the presence of a low grade in situ ductal carcinoma microfocus located $0.5 \mathrm{~mm}$ from the lower limit and a microfocus of lobular carcinoma in situ located $0.5 \mathrm{~mm}$ from the deep limit. There was a theoretical indication for left breast radiotherapy but given the size of the DCIS and its grade, as well as the history of irradiation nearby, it was decided not to perform adjuvant therapy. Six months later, the patient did not show signs of relapse.

\section{Discussion}

PSCCBs are very rare malignant tumors. Due to the low incidence of this disease, no randomized or prospective studies have been published. Moreover, its prevalence, its prognosis, its optimal diagnostic

*Correspondence to: Karl Wehbe, Department of Surgery, Institut Jean Godinot - Unicancer, 1 rue du Général Koenig CS80014, 51726 Reims, France, Tel: 33622916162; E-mail: wehbekarl@gmail.com

Received: August 02, 2018; Accepted: August 17, 2018; Published: August 20 2018 


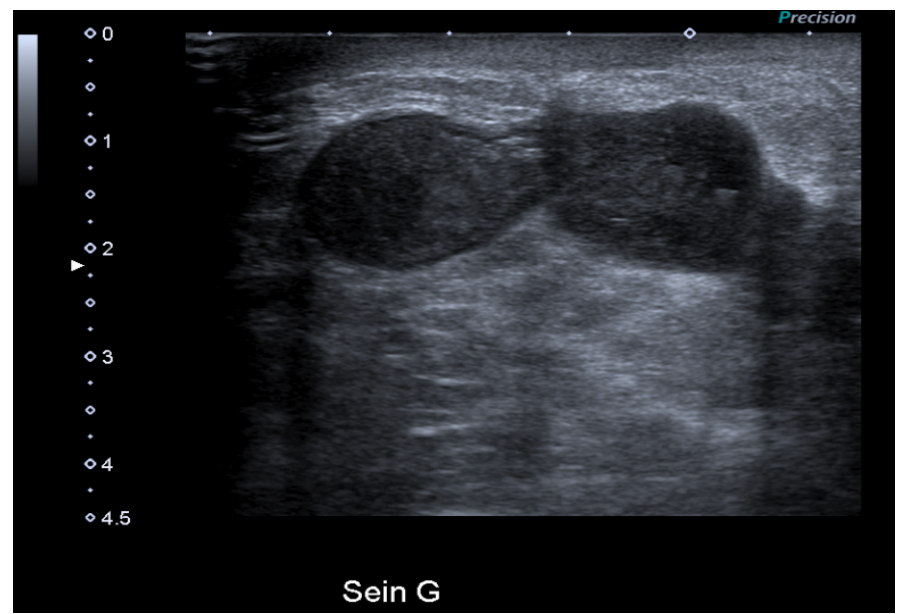

Figure 1. Breast ultrasound. Bilobed cyst. No lymphadenopathy visualized. No argument for a local recurrence of the disease

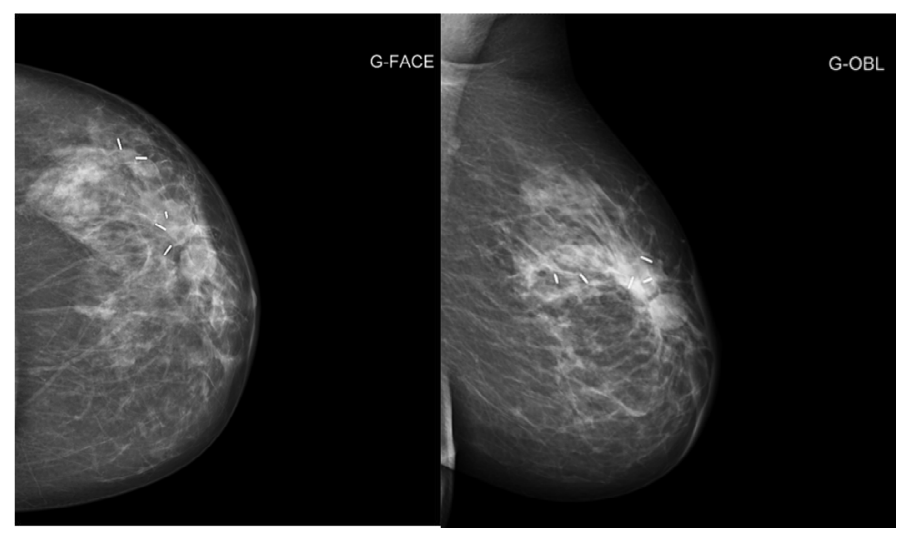

Figure 2. Left mammography. Lymphocele under the scar of the first lumpectomy. Radiologically benign appearance

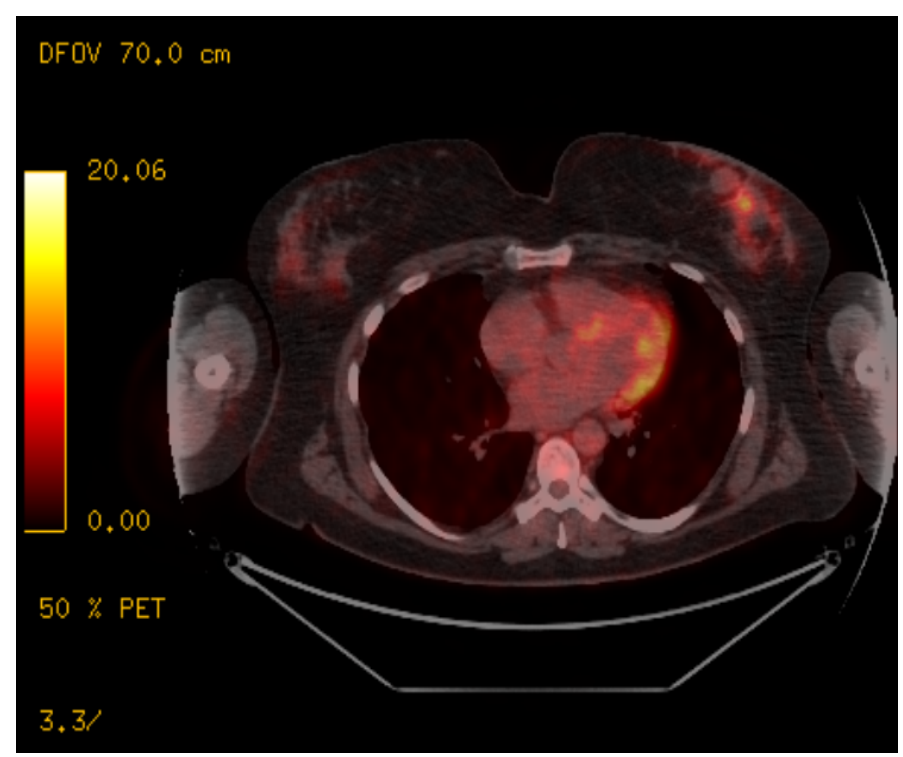

Figure 3. PET scan. Appearance of a left lobular retro-nipple-shaped nodular image with heterogeneous peripheral hypermetabolism

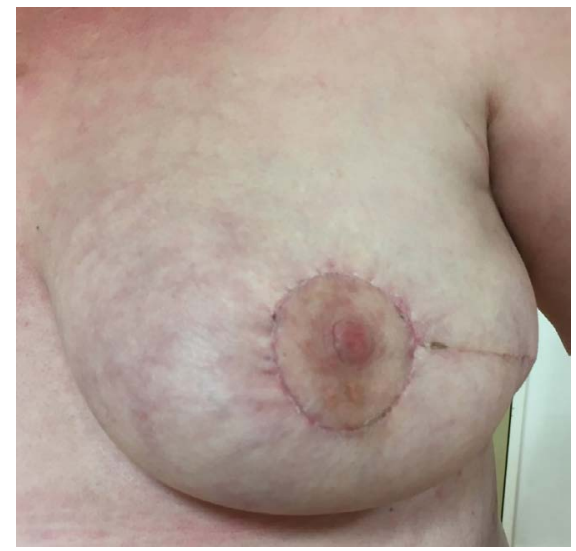

Figure 4. Postoperative result. After the last conservative partial mastectomy, level 2 oncoplasty

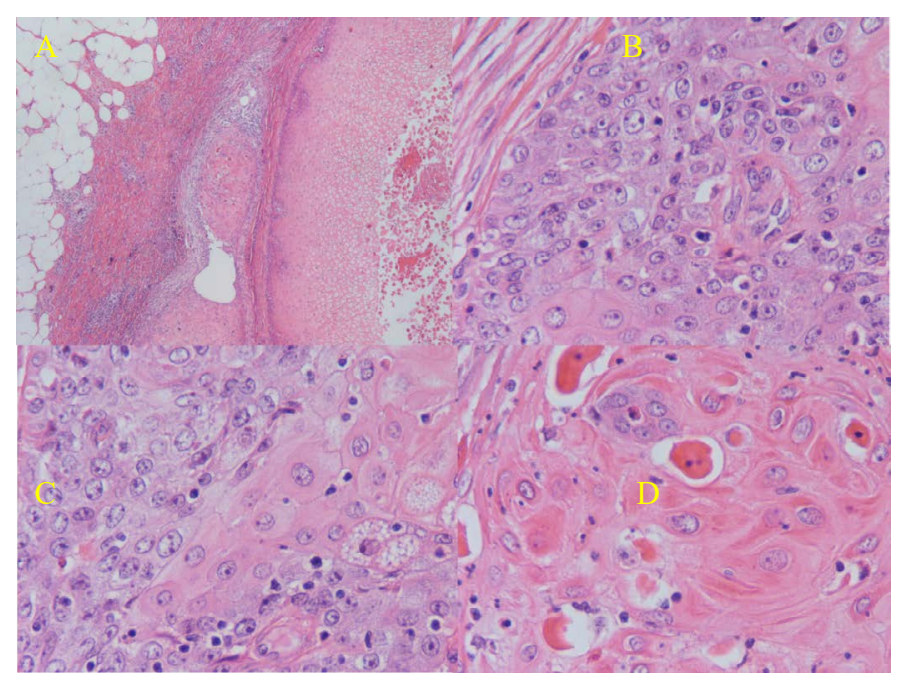

Figure 5. Histology. (A) Cystic lesion, with squamous cell carcinoma. Lymphatic invasion, inflammatory infiltrate of the stroma; (B,C) Cells with a variable degree of nuclear atypia, pleomorphism and epidermoid differentiation. (D) Well-differentiated portions with tight junctions and dyskeratosis

and therapeutic management remain debated. PSCCBs appear to have the following characteristics: rapid progression, tendency to form cysts with abcedation suggestive of a benign inflammatory disease that may lead to diagnostic delays, and relative chemoresistance with hormonal receptor negativity [10].

The definition of PSCCB is slightly different between the WHO, for which it is defined by "breast carcinoma entirely composed of metaplastic squamous cells that can be keratinizing, non-keratinizing or tapered; they are not derived from the overlying skin nor represent metastases from other sites "and the Rosen's Breast Pathology for which pure epidermoid forms are defined by" the presence of a squamous component in more than $90 \%$ of tumor cells" $[1,2]$. As a result, the older publications include, as BCSCC, certain forms of metaplastic squamous cell carcinoma of the breast. Its incidence is difficult to assess, often estimated at about $0.1 \%$ of breast cancers [9,11-14]. It is a cancer that affects women of all ages with an average often around 55 years. 
The histogenesis of these tumors is poorly known, it is thought to come directly from the mammary ductal epithelium, although other authors defend the hypothesis that the origin of the tumor lies on the areas of squamous metaplasia at within a persistent breast adenocarcinoma [15]. For some authors, it can be developed from a chronic abscess, mastitis or cyst, which may explain certain clinical or radiological presentation modes [7]. In all cases, it is necessary to check the absence of skin invasion at the level of the skin or the nipple, and to eliminate a possible epidermoid primitive at a distance [16].

This pathology is most often of symptomatic discovery with a palpable tumor of significant size: $30 \mathrm{~mm}$ for our patient, in the literature, it often oscillates around $60 \mathrm{~mm}[9,11-14,17]$. Their growth is often rapid, causing these tumors to escape detection. Several cases have been revealed by the presence of a breast abscess, any flattening must be accompanied by histological samples [18-22]. Presentations on prosthesis or pregnant women, although exceptional, are not isolated cases [22-26].

The radiologic semiology is not very specific, often taking the form of a rounded, cystic mass with contours that may be irregular $[10,11]$.

Histologically, these tumors are most often of the triple negative type but can, in rare cases, express hormonal receptors with or without Her2 amplification [27-31].

The ganglionic invasion seems to be frequent, in the literature, the frequency is variable with a probable association between the tumor size and the ganglionic attack [7].

Surgical treatment is the key element in the management of PSCCBs with between 50 to $90 \%$ mastectomies and 60 to $90 \%$ axillary dissection depending on the series $[11,12,14]$. The initial size of the lesion often makes radical treatment inevitable. Few studies currently evaluate the place of the Sentinel Axillary Ganglia in this pathology.

Chemotherapy in this pathology is poorly evaluated. No studies have shown the benefit of chemotherapy in terms of survival. Over the last 10 years, the most common patterns are either those of other more common breast cancers or platinum-based protocols. Their efficiencies remain to be evaluated as well as the indications.

Adjuvant radiotherapy is also debated in the management of the CCBP. Although it seems frequently used in the series, no solid data has shown a benefit in terms of survival. As radiotherapy has a significant role in the management of other squamous cell carcinoma sites, with in some cases comparable to surgery, it seems legitimate to use it in the absence of specific breast data [32].

Commonly, PSCCBs are considered to be cancers with poor prognosis, close to so-called triple negative breast cancers. Survival at 5 years in recent series varies between 35 and $70 \%[12,14]$. Further studies with larger numbers and longer follow-up periods would provide more detail on this issue.

\section{Conclusion}

PSCCBs are rare cancerous tumors that are part of metaplastic breast cancers. Their diagnoses are often made in the presence of an already bulky mass because of a fast growth, with a cystic aspect to see of breast abscess. It is a pathology of the woman over 50 but can also be seen in younger patients. The therapeutic management is primarily surgical mainly through radical surgeries because of the often-large size of these tumors. Lymph node involvement is common. The efficacy of adjuvant treatments remains to be assessed for both radiotherapy and chemotherapy. For the moment, their indications are not the subject of any consensus. Due to the rarity of these tumors, it is difficult to collect accurate data to support these issues. The clinical cases found in the literature describe quite precisely the diagnostic and therapeutic approaches implemented but with often insufficient survival data to study the prognosis of these cancers and the effectiveness of adjuvant therapies. The clinical and histological features of these tumors seem to be increasingly understood, however further work is needed in the evaluation of the therapeutic management and prognostic factors of this disease.

\section{References}

1. Reis-Filho JS, Lakhani SR, Gobbi H, Sneige N (2012) Metaplastic carcinoma. In Lakhani SR, Ellis IO, Schnitt SJ, et al, eds. WHO Classification of Tumours of the Breast. 4th edition. Lyon, France: IARC, pp: 48-52.

2. Rosen PR (2001) Rosen's Breast Pathology. Chapter 19. Philadelphia, PA: Lippincott Williams \& Wilkins; 2001: 455-461.

3. Wrightson WR, Edwards MJ, McMasters KM (1999) Primary squamous cell carcinoma of the breast presenting as a breast abscess. Am Surg 65: 1153-1155. [Crossref]

4. Menes T, Schachter J, Morgenstern S, Fenig E, Lurie H, et al. (2003) Primary squamous cell carcinoma (SqCC) of the breast. Am J Clin Oncol 26: 571-573. [Crossref]

5. Weigel RJ, Ikeda DM, Nowels KW (1996) Primary squamous cell carcinoma of the breast. South Med J 89: 511-515. [Crossref]

6. Cardoso F, Leal C, Meira A, Azevedo R, Mauricio MJ, et al. (2000) Squamous cell carcinoma of the breast. Breast 9: 315-319. [Crossref]

7. Aparicio I, Martínez A, Hernández G, Hardisson D, De Santiago J (2008) Squamous cell carcinoma of the breast. Eur J Obstet Gynecol Reprod Biol 137: 222-226. [Crossref]

8. Grabowski J, Saltzstein SL, Sadler G, Blair S (2009) Squamous cell carcinoma of the breast: a review of 177 cases. Am Surg 75: 914-917. [Crossref]

9. Nayak A, Wu Y, Gilcrease MZ (2013) Primary squamous cell carcinoma of the breast predictors of locoregional recurrence and overall survival. Am J Surg Pathol 37: 867873. [Crossref]

10. Honda M, Saji S, Horiguchi S, Suzuki E, Aruga T, et al. (2011) Clinicopathological analysis of ten patients with metaplastic squamous cell carcinoma of the breast. Surg Today 41: 328-332. [Crossref]

11. Mychaluk J, Baron M, Fondrinier E, Laberge S, Gondry J, et al. (2012) Primary squamous cell carcinoma of the breast: clinical study and review of the literature. Bull Cancer 99: 771-778. [Crossref]

12. Liu J, Yu Y, Sun J, He S, Wang X, et al. (2015) Clinicopathologic characteristics and prognosis of primary squamous cell carcinoma of the breast. Breast Cancer Res Treat 149: 133-140. [Crossref]

13. Pai T, Shet T, Desai S, Patil A, Nair N, et al. (2016) Impact of Squamous Differentiation in Breast Carcinoma. Int J Surg Pathol 24: 483-489. [Crossref]

14. Zhang X, Zhang B, Zang F, Zhao L, Yuan Z, et al. (2016) Clinical features and treatment of squamous cell carcinoma of the breast. Onco Targets Ther 9: 3181-3185. [Crossref]

15. Farrand R, Lavigne R, Lokich J, McAuley R, Sparling S, et al. (1979) Epidermoid carcinoma of the breast. J Surg Oncol 12: 207-211. [Crossref]

16. Gupta N, Vashisht R, Nimbran V, Gupta R, Dhingra N, et al. (2012) Primary squamous cell carcinoma of the breast: case report and management decisions. J Cancer Res Ther 8: 323-325. [Crossref]

17. Wang J, Zhang X, He J, Yang M, Tang J, et al. (2014) Co-expression of EGFR and CK5/6 in primary squamous cell carcinoma of the breast. Med Oncol 31: 172. [Crossref]

18. Bhatt L, Fernando I (2009) Primary squamous cell carcinoma of the breast: achieving long-term control with cisplatin-based chemotherapy. Clin Breast Cancer 9: 187-188. [Crossref]

19. Salemis NS (2011) Breast abscess as the initial manifestation of primary pure squamous cell carcinoma: a rare presentation and literature review. Breast Dis 33: 125131. [Crossref]

20. Kurpad V, Prabhu K C, Ramesh MK, Harindranath HR (2013) Primary denovo squamous cell carcinoma breast masquerading as breast abscess. Indian $J$ Surg Oncol 4: 48-51. [Crossref] 
21. Seddik Y, Brahmi SA, Afqir S (2015) Primary squamous cell carcinoma of the breast: a case report and review of literature. Pan Afr Med J 20: 152. [Crossref]

22. Zomerlei TA, Samarghandi A, Terando AM (2015) Primary Squamous Cell Carcinoma Arising from a Breast Implant Capsule. Plast Reconstr Surg Glob Open 3: e586. [Crossref]

23. Ashindoitiang JA, Faduyile FA, Taiwo OJ (2011) Primary Squamous Cell Carcinoma of the Breast during Pregnancy: A Case Report. Case Rep Med 2011: 327029. [Crossref]

24. Kitchen SB, Paletta CE, Shehadi SI, Bauer WC (1994) Epithelialization of the lining of a breast implant capsule. Possible origins of squamous cell carcinoma associated with a breast implant capsule. Cancer 73: 1449-1452. [Crossref]

25. Rokutanda N, Iino Y, Yokoe T, Maemura M, Horiguchi J, et al. (2000) Primary squamous cell carcinoma of the breast during lactation: a case report. Jpn J Clin Oncol 30: 279-282. [Crossref]

26. Senga O, Hikita H, Kinoshita T, Hara K, Miyakawa M, et al. (1993) Primary squamous cell carcinoma of the breast in a pregnant woman: report of a case. Surg Today 23: 541-545. [Crossref]
27. Flikweert ER, Hofstee M, Liem MS (2008) Squamous cell carcinoma of the breast: a case report. World J Surg Oncol 6: 135. [Crossref]

28. Cilekar M, Erkasap S, Oner U, Akici M, Ciftci E, et al. (2015) An atypical cause of rapidly progressing breast lump with abscess formation: Pure squamous cell carcinoma of the breast. J Cancer Res Ther 11: 1023. [Crossref]

29. Pribish AM, Saglam O, Weinfurtner RJ (2017) Estrogen receptor-positive primary squamous cell carcinoma of the breast. Radiol Case Rep 12: 211-214. [Crossref]

30. Cha N, Wang S, Lv M, Wang DW, Zhang XJ, et al. (2018) Breast Metaplastic Squamous Cell Carcinoma Diagnosed with Fine Needle and Core Biopsy: A Case Study. Am J Case Rep 19: 203-206. [Crossref]

31. Stolnicu S, Bauer O, Fetyko A, Zaharia-Kézdi EI, Andrejkovits ÁV, et al. (2018) Primary infiltrating squamous cell carcinoma of the breast with Basal-HER2 phenotype developed in an HIV-infected woman. Breast $J$. [Crossref]

32. Skulsky SL, O'Sullivan B, McArdle O, Leader M, Roche M, et al (2017) Review of high-risk features of cutaneous squamous cell carcinoma and discrepancies between the American Joint Committee on Cancer and NCCN Clinical Practice Guidelines In Oncology. Head Neck 39: 578-594. [Crossref]

Copyright: (C2018 Wehbe K. This is an open-access article distributed under the terms of the Creative Commons Attribution License, which permits unrestricted use, distribution, and reproduction in any medium, provided the original author and source are credited. 